\title{
Differentiated Integration, Reconsidered
}

\author{
Hartmut Marhold*
}

\section{A new U-turn to multi-speed Europe}

"The history of recent years has shown that there will be a multi-speed $\mathrm{EU}$, and not all members will participate in the same steps of integration", said Angela Merkel after the informal EU-Summit at Valetta/Malta, 3 February 2017 - "it was the first time that Merkel clearly claimed this old idea as her own." It amounts to a U-turn in Merkel's EU-integration strategy; until now, she has, in fact, pinned all her hopes on advancing towards tighter and tougher integration with all the - 27! - Member States of the Union. She is not the only one to switch from a one-fits-all approach to differentiated integration: François Hollande agreed as much on the idea ${ }^{2}$ at the same time as the Italian government, and the three Benelux-countries went as far as to publish an official statement on the topic. "Different paths of integration and enhanced cooperation could provide for effective responses to challenges that affect member states in different ways. These arrangements should be inclusive and transparent, with the greatest possible involvement of the other member states and EU institutions." 3 This means that all the six founding Member States agreed, almost at the same moment, on a strategy of integration which is certainly not new, from a historical perspective, but has not been part of the game plan since the Brexit vote and the so-called Bratislava road-map, agreed upon in September 2016 and aiming at a reform vision for the EU to be achieved at the 60th anniversary of the Rome Treaties, in March 2017. Last but not least, the President of the Commission joined the chorus: "I think the time has come for us to answer this historic question: do we want to move forward - as a group of 28 - in fact, we've already lost the 28th - or should those who want to move forward faster do so without bothering the others, by putting in place a better structure, open to all?' Juncker asked, adding that he would 'argue for this' in the coming days." 4 What has led to Angela Merkel, on behalf of Germany, and the other founding member states changing their minds? And what can a "multi-speed" Europe, what can "different paths and enhanced cooperation" mean? 


\section{The dilemma - pros and cons}

The challenge is obvious and is openly addressed in all of the three reports on EU reform ${ }^{5}$ voted by the European Parliament on the $22^{\text {nd }}$ February. One of these introduced by the Committee on Constitutional Affairs, chaired by Mercedes Bresso and Elmar Brok, outlines the problem: "The European Union and its Member States are facing unprecedented challenges, such as the refugee crisis, the foreign policy challenges in the immediate neighbourhood and the fight against terrorism, as well as globalisation, climate change, demographic developments, unemployment, the causes and consequences of the financial and debt crisis, the lack of competitiveness and the social consequences in several Member States, and the need to reinforce the EU internal market, all of which need to be more adequately addressed." The report underlines "that these challenges cannot be adequately tackled individually by the Member States but need a collective response from the Union, based on respect for the principle of multi-tier governance."

But this view is just not unanimously shared throughout Europe - not only did a relative majority of the British electorate vote to "leave" the EU, but populist parties all-over Europe promise a re-nationalisation of competences. Somebody like Nigel Farage, a most ardent proponent of the "Leave" campaign in the UK, at the time UKIP president and still Member of the European Parliament, took the floor in the debate about the aforementioned three reports: "Mr. Verhofstadt this morning said the people want more Europe. They do not: the people want less Europe", and qualified those who were in favour of deeper integration as a "religious sect".

Not least, the Visegrad-countries - Poland, the Czech Republic, Slovakia and Hungary - took a divergent stance, both before and after the Bratislava meeting, pleading for re-nationalisation; their primary concern being ,to strengthen the role of national parliaments, underlining respect for the principles of subsidiarity and proportionality"; and already "We believe it's up to national parliaments to have the final word on the decisions of the European Commission," confirmed the Polish Prime Minister, Beata Szydlo. This is the reason why these countries are strictly opposed to differentiated integration - their fear is that others would take steps towards a more integrated Europe which they do not agree with: "the Visegrad Countries insist that European integration is a common project and all negotiations should therefore be inclusive and open to all Member States." 
And that is the dilemma: Either enable the European Union to find effective solutions to the problems by increasing its areas of jurisdiction, budgets, power - and then accept that not all of the remaining 27 Member States will go this way; or stick to the idea that the Union as a whole should be held together at the same level of integration - and then accept that the problems cannot be solved. The momentum is in favour of the first option. That is why it is relevant to rethink differentiated integration under the current circumstances. The following reflection aims to pave the way for such a reflection.

\section{The triangle of realism: Member States, policies and methods}

Deeper integration among several Member States maybe a way to advance, in terms of European unification - but it soon becomes a dream if the real conditions under which this can happen, are not met. There are three fundamental conditions which must come together in order to allow for differentiated integration: First, one must identify Member States which are ready to go for more European political unity, which are committed to a strengthened Union, convinced that an enhanced Union can and will offer better solutions to problems and that such a move will be welcomed by their electorate. In other terms, the task of finding a way to deeper integration with less than the whole range of Member States must be envisaged from the perspective of the Member States, more than from the level of the Union.

Second, there must be policies which are arguably more effectively driven forward at the European level than at the level of the Member States. Differentiated integration can probably not be achieved by renforcing and empowering the constitutional system and institutions of the EU, endowing them with greater competences, if there is not a set of policies to which this empowerment actually applies. There are candidates, among the policies, which until now have either been in the hands of the Member States, or in the hands of the Union, or shared between both: Juncker, in his speech in Louvain-la-Neuve, quoted defence or research as examples; others refer to the economic governance of the $€$-Zone, growth or social policy, migration and security. Whatever the policy, the choice is crucial, and must hold the promise of an increased problem solving capacity for those who go for more integration in the chosen field. 
Third, there must be appropriate models for the further and deeper integration of fewer than 27 Member States. The choice is confusing, and not all of the methods, instruments, and structures are equally promising. The choice of an appropriate form of differentiated integration is as crucial in terms of its chances of being implemented as the choice of Member States and policies. The next argument sets out to specifically address this aspect, but one thing is already clear: An advancement towards differentiated integration needs all the aforementioned three factors simultaneously Member States, that are willing to join; policies which promise to be successfully led at the European level; and forms of differentiation - appropriate for those Member States and these policies. Only if these three criteria are met can differentiated integration stand a chance of succeeding. One may imagine this set of conditions in the configuration of a triangle, as shown below. This triangle is exclusive, too: It does not make much sense to look for policies which might indeed be better conducted at the European level, if there are in fact no Member States willing to transfer the corresponding competence to the Union. And there may be forms and methods of differentiated integration which seem to be ingenious, but they are irrelevant as long as there are no policies to which they can be applied with the consent of a set of Member States. The focus of any further reflection should therefore be given to those issues which unite all three conditions - Member States, policies and appropriate forms of integration - under one project.

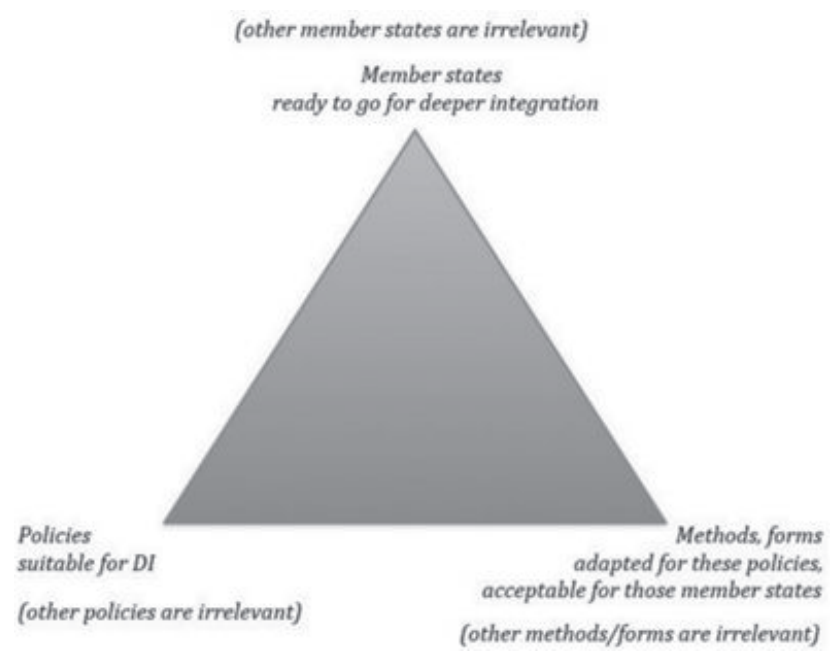


Differentiated integration is beneficial for the EU only if it does not initiate a definite divide, but if it develops an attractive dynamic.

No Member State aims at reducing the number of participants for further and deeper integration; those who plead for differentiated integration consider that leaving others behind is a high price to pay, and would wish them to join. The ultimate aim is, in any case, to convince those who do not participate, to join. We therefore need to take a closer look at the different forms and methods of differentiated integration to assess their potential to serve that aim. And the forms and methods of differentiation are indeed very different with regard to this criterion. The choice should, then, be based on the attractiveness of the method, its openness to latecomers, its dynamic potential to pull them into the club, instead of pushing them into the second rank. At the opposite end of the spectrum would be those forms of differentiated integration which appear to be exclusive, do not contain a dynamic attractiveness, would cement the divide between participants and sceptics and create barriers which would be difficult to overcome in the case of a non-participant changing direction and wishing to join later. The two extremes seem to be a "hard core" Europe on the one hand, and an "avant-garde" on the other - the one, exclusive and stabilising, the other, potentially inclusive and dynamically attractive.

Many different forms of differentiated integration have been put into practice over the 67 years of European integration, since the launch of the European Community for Coal and Steel, in 1950. One may even consider the start with only six founding Member States as an attractive form of differentiated integration, since so many others felt attracted enough to join over time. "The Six" were a pioneer group, an avant-garde, and therefore displayed those attractive qualities which can unfold if a small group decides to go ahead. It comes as no surprise, then, that these Six, sometimes joined by one or the other later member (like Spain, today), after experiencing a sustained European success, are still ready to go for the next step. Whatever the case, differentiated integration has always been a way to move forward at those times when not all Member States have been ready to join.

The last Treaties, and in particular the Lisbon Treaty, even enshrines forms of differentiation which can therefore be implemented under the provisions of the current Treaty, and do not need a split between Member States over primary law: "Enhanced Integration" (or, with regard to defence issues, "permanent structured cooperation") is an option within the 
Treaty itself. ${ }^{7}$ It is by nature open to all the Member States, and fulfils the criterion of openness without any restraint. The Brok-Bressot Report puts all its hopes on the use of the unexploited potential of the Lisbon Treaty, and much depends on whether or not the Member States will trigger this option of advancing, and whether they will use the so-called "passerelle clause", which allows for qualified decision making among those who opted for "enhanced integration". The disadvantage, however, of the "enhanced integration" method is that it requires unanimity - all the Member States must give their consent that some of them go for further and deeper integration, even if they do not wish for deeper integration to take place; and that is an obstacle which may block an advance under this provision.

Many other forms of differentiated integration have been discussed and an important number of them has been implemented and experienced. Opt-outs and opt-ins are still close to forms of integration enshrined in the same primary law agreed upon by all the Member States, and constitute a rather durable form of differentiation. Close to "(hard) core Europe" is the idea of "concentric circles", which does not suggest an attractive dynamic either. The same is true for "Variable geometry", despite its greater flexibility, because it does not assume that there is only one inner circle which agrees on the highest level of integration in all fields; "variable geometry" allows for overlapping circles, where various groups of Member States do different things together. - The disadvantage in this case is not so much its exclusiveness, but its complexity. A similar concept is a "Europe à la carte" which would allow for an unlimited choice of steps towards more integration in policy fields which seem to be advantageous in the eyes of individual Member States - a method, which is particularly problematic with regard to solidarity, and comes close to cherry picking.

The more attractive, dynamic concepts of differentiated integration contain a hint to the timeline: "multi-speed Europe", "avant-garde" or "pioneer group" all refer to the idea that all of the Member States are on the move, that they are all moving in the same direction, but that some of them are advancing quicker than the others. "Avant-garde" and "pioneer group", taken literally, even add the idea that they are exploring and paving the way for the other members who are supposed to follow, once the leading group has proved to be successful. 


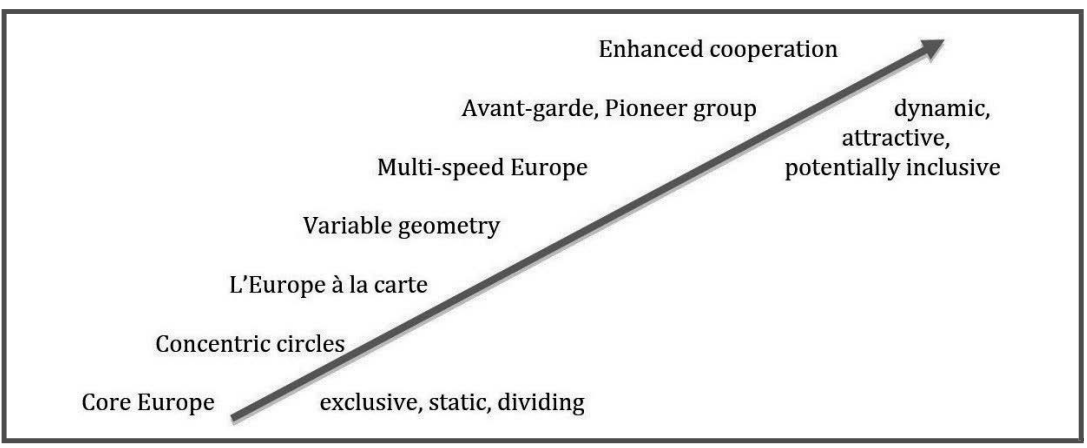

\section{Conclusion}

Differentiated integration should be used cautiously because the price is high, and should be seen as a realistic key (and not as a straight way towards European federalisation). It may be a solution if there are policies, Member States and appropriate methods which converge and if the specific form of differentiated integration these member states initiate in those fields stays attractive for the rest of the EU, i.e. if it has the potential to unify Europe at a higher level, instead of dividing it.

*Hartmut Marhold is Senior Research Fellow at CIFE.

\section{References:}

1 Merkel quoted after Deutsche Welle: „German Chancellor Merkel 'working to hold the EU together'“, 8 February 2017; http:// www.dw.com/en/german-chancellor-merkel-working-to-hold-the-eutogether/a-37464058. Merkels turn was reported and commented in nearly all the important German media.

2 See Le Monde, 21 février 2017: http://www.lemonde.fr/europe/ article/2017/02/21/paris-et-berlin-misent-sur-1-europe-a-plusieurs- vitesses_5082670_3214.html, where even a new format of four countries (France, Germany, Italie and Spain) is said to meet in order to prepare a multi-speed vision for Europe: see also Les Echos, 5 February 2017; http://www.lesecho.fr/monde/europe/0211777218353-leurope-aplusieurs-vitesses-ressurgit-au-60eme-anniversaire-du-traite-derome-2062717.php. 
3 Quoted after the italian Think-Tank, Astrid': http://www.Pastrid-online.it/static/upload/protected/bene/benelux_press-release.pdf

4 Georgi Gotev (on behalf of Euractiv): Juncker: This Commission no longer regulates the flushing of toilets, 24 February 2017; http:// www.euractiv.com/section/future-eu/news/juncker-this-commissionno-longer-regulates-the-flushing-of-toilets/

5 These three reports are:

- REPORT on improving the functioning of the European Union building on the potential of the Lisbon Treaty, elaborated by the Committee on Constitutional Affairs; Rapporteurs: Mercedes Bresso, Elmar Brok (http://www.europarl.europa.eu/sides/getDoc.do?type=RE-

PORT\&mode $=X M L \&$ reference $=$ A8-2016-0386\&language $=E N$ )

- REPORT on possible evolutions of and adjustments to the current institutional set-up of the European Union, elaborated by the Committee on Constitutional Affairs; Rapporteur: Guy Verhofstadt (http:// www.europarl.europa.eu/sides/ getDoc.do?type=REPORT\&reference $=\mathrm{A} 8-2016-0390$ \&language $=\mathrm{DE}$ )

- REPORT on budgetary capacity for the Eurozone, elaborated by the Committee on Budgets, Committee on Economic and Monetary Affairs; Rapporteurs: Reimer Böge, Pervenche Berès (http:// www.europarl.europa.eu/sides/getDoc.do?type=RE-

PORT\&mode $=X M L \&$ reference $=$ A8-2017-0038\&language $=E N$ )

The extensive debate in the Plenary is available here: http:// www.europarl.europa.eu/sides/getDoc.do?pubRef=-//EP// TEXT+CRE +20170214+ITEM-002+DOC+XML+V0//

DE\&language $=$ de $\&$ query $=$ INTERV $\&$ detail $=2-011-000$

6 Whereas „Beata Szydlo and her country are normally opponents of this idea, but she did not contradict Merkel this time" (http:// www.dw.com/en/german-chancellor-merkel-working-to-hold-the-eu -together/a-37464058), i.e. when Merkel was in Warsaw, 7 February; more outspoken was the leader of ruling party in Poland: "Poland's Kaczynski warns two-speed Europe leads to 'breakdown'." https:// www.euractiv.com/section/future-eu/news/polands-kaczynski-warnstwo-speed-europe-leads-to- breakdown/

7 A short overview, as profound and reliable as readable for all those who are not lawers: http://eur-lex.europa.eu/legal-content/GA/ALL/? uri=uriserv:ai0018 